\title{
The Nitrogen-Assisted Triphenylphosphine Displacement of Methylpyridine Ligand in Palladium(II) Complex: Crystal Structures of $\left[\mathrm{Pd}\left(\mathrm{PPh}_{3}\right)_{2}\left\{\eta^{1}-\mathrm{C}_{5} \mathrm{H}_{3} \mathrm{~N}\left(\mathrm{CH}_{3}\right)\right\}(\mathrm{Br})\right]$ and $\left[\mathrm{Pd}\left(\mathrm{PPh}_{3}\right) \mathrm{Br}\right]_{2}\left\{\mu, \eta^{2}-\mathrm{C}_{5} \mathrm{H}_{3} \mathrm{~N}\left(\mathrm{CH}_{3}\right)\right\}_{2}$
}

\author{
Kuang-Hway Yih ${ }^{\mathrm{a} *}$ ( 易光輝) and Gene-Hsiang Lee ${ }^{\mathrm{b}}$ ( 李錦祥) \\ ${ }^{a}$ Department of Applied Cosmetology, Hungkuang University, Shalu, Taichung, Taiwan 433, R.O.C. \\ ' Instrumentation Center, College of Science, National Taiwan University, Taipei, Taiwan 106, R.O.C.
}

\begin{abstract}
Treatment of $\mathrm{Pd}\left(\mathrm{PPh}_{3}\right)_{4}$ with 2-bromo-4-methylpyridine, $\mathrm{C}_{5} \mathrm{H}_{3} \mathrm{~N}\left(\mathrm{CH}_{3}\right) \mathrm{Br}$, in dichloromethane at $-20{ }^{\circ} \mathrm{C}$ causes the oxidative addition reaction to produce the palladium complex $\left[\mathrm{Pd}\left(\mathrm{PPh}_{3}\right)_{2}\left\{\eta^{1}-\mathrm{C}_{5} \mathrm{H}_{3} \mathrm{~N}\left(\mathrm{CH}_{3}\right)\right\}(\mathrm{Br})\right]$, $\mathbf{2}$, by substituting two triphenylphosphine ligands. In a dichloromethane solution of complex $\mathbf{2}$ at room temperature for $3 \mathrm{~h}$, it undergoes displacement of the triphenylphosphine ligand to form the dipalladium complex $\left[\mathrm{Pd}\left(\mathrm{PPh}_{3}\right) \mathrm{Br}\right]_{2}\left\{\mu, \eta^{2}-\mathrm{C}_{5} \mathrm{H}_{3} \mathrm{~N}\left(\mathrm{CH}_{3}\right)\right\}_{2}, \mathbf{3}$, in which the two 4-methylpyridine ligands coordinated through carbon to one metal center and bridging the other metal through the nitrogen atom. Complexes 2 and $\mathbf{3}$ are characterized by X-ray diffraction analyses.
\end{abstract}

Keywords: 2-Bromo-4-methylpyridine; Palladium; Dipalladium; Nitrogen-assisted; X-ray diffraction.

\section{INTRODUCTION}

Palladium complexes catalyzed forming $\mathrm{C}-\mathrm{C}$ and $\mathrm{C}-\mathrm{X}$ bond processes are the most important reactions in organic synthesis. ${ }^{1}$ Especially, palladium-nitrogen containing complexes have been employed in applications in the synthesis of heterocycles, i.e. thiazoles, ${ }^{2}$ imidazoles, ${ }^{3}$ pyrroles $^{4}$ and indoles. ${ }^{5}$

Intramolecular reductive elimination of Pd-N binuclear complex $\left[\mathrm{Pd}\left(\mu-\mathrm{C}_{9} \mathrm{H}_{6} \mathrm{~N}\right)(\mu \text {-dppm })\right]_{2}(\mathrm{Cl})_{2}$ yielding organic compound 2,2'-biquinoline and complex $\left[\mathrm{Pd}_{2} \mathrm{Cl}_{2}-\right.$ $\left.(\mathrm{dppm})_{2}\right]^{6}$ has been reported. A. Beeby reported a pyridylbridged palladium complex as an effective precatalyst for the Suzuki cross-coupling reactions of a variety of organoboronic acids and aryl bromides. ${ }^{7}$

Recently we reported syntheses, reactivities, interand intramolecular dissociation, and crystal structures of Pd complexes containing thiocarbamoyl, ${ }^{8}$ oxythiocarbon$\mathrm{yl},{ }^{9}$ and thiazoliny $\mathrm{l}^{10}$ moieties. These ligands induced forming binuclear complexes in which those were assisted by nitrogen or sulfur atoms. In order to obtain a better understanding of how these ligands interact with the metal center and the following study for applications in organic synthesis, we report the synthesis and crystal structures of palladium complexes including the 4-methylpyridine con- taining ligand in this paper.

\section{RESULTS AND DISCUSSION}

Treatment of $\mathrm{Pd}\left(\mathrm{PPh}_{3}\right)_{4}, 1$ with 2-bromo-4-methylpyridine, $\mathrm{C}_{5} \mathrm{H}_{3} \mathrm{~N}\left(\mathrm{CH}_{3}\right) \mathrm{Br}$, in dichloromethane at $-20{ }^{\circ} \mathrm{C}$ yields the colorless complex $\left[\mathrm{Pd}\left(\mathrm{PPh}_{3}\right)_{2}\left\{\eta^{1}-\mathrm{C}_{5} \mathrm{H}_{3} \mathrm{~N}\left(\mathrm{CH}_{3}\right)\right\}-\right.$ (Br)], 2 with $92 \%$ isolated yield (Scheme I). The air-stable colorless compound $\mathbf{2}$ is soluble in dichloromethane and acetonitrile, slightly soluble in methanol, and insoluble in diethyl ether and $n$-hexane. By continuous stirring the dichloromethane solution of complex 2 at room temperature for $3 \mathrm{~h}$, the displacement of triphenylphosphine by nitrogen atom from the other 4-methylpyridine-metal complex yielded the air-stable colorless dipalladium complex $\left[\mathrm{Pd}\left(\mathrm{PPh}_{3}\right) \mathrm{Br}\right]_{2}\left\{\mu, \eta^{2}-\mathrm{C}_{5} \mathrm{H}_{3} \mathrm{~N}\left(\mathrm{CH}_{3}\right)\right\}_{2}, 3$ with $95 \%$ isolated yield.

The spectroscopic and analytical data of $\mathbf{2}$ and $\mathbf{3}$ are in good agreement with the formulation. The FAB mass spectra of $\mathbf{2}$ and $\mathbf{3}$ show parent peaks with the typical Pd isotope distribution corresponding to $\left[\mathrm{M}^{+}\right]$molecular mass, respectively. The ${ }^{31} \mathrm{P}\left\{{ }^{1} \mathrm{H}\right\}$ and ${ }^{1} \mathrm{H}$ NMR spectra of $\mathbf{2}$ and $\mathbf{3}$ are similar. The ${ }^{31} \mathrm{P}\left\{{ }^{1} \mathrm{H}\right\}$ NMR spectra of $\mathbf{2}$ and $\mathbf{3}$ show singlet resonances at $\delta 26.6$ and $\delta 30.4$, respectively. In the ${ }^{1} \mathrm{H}$ NMR spectra, the protons of the methyl group exhibit one singlet

\footnotetext{
* Corresponding author. E-mail: khyih@sunrise.hk.edu.tw
} 


\section{Scheme I}

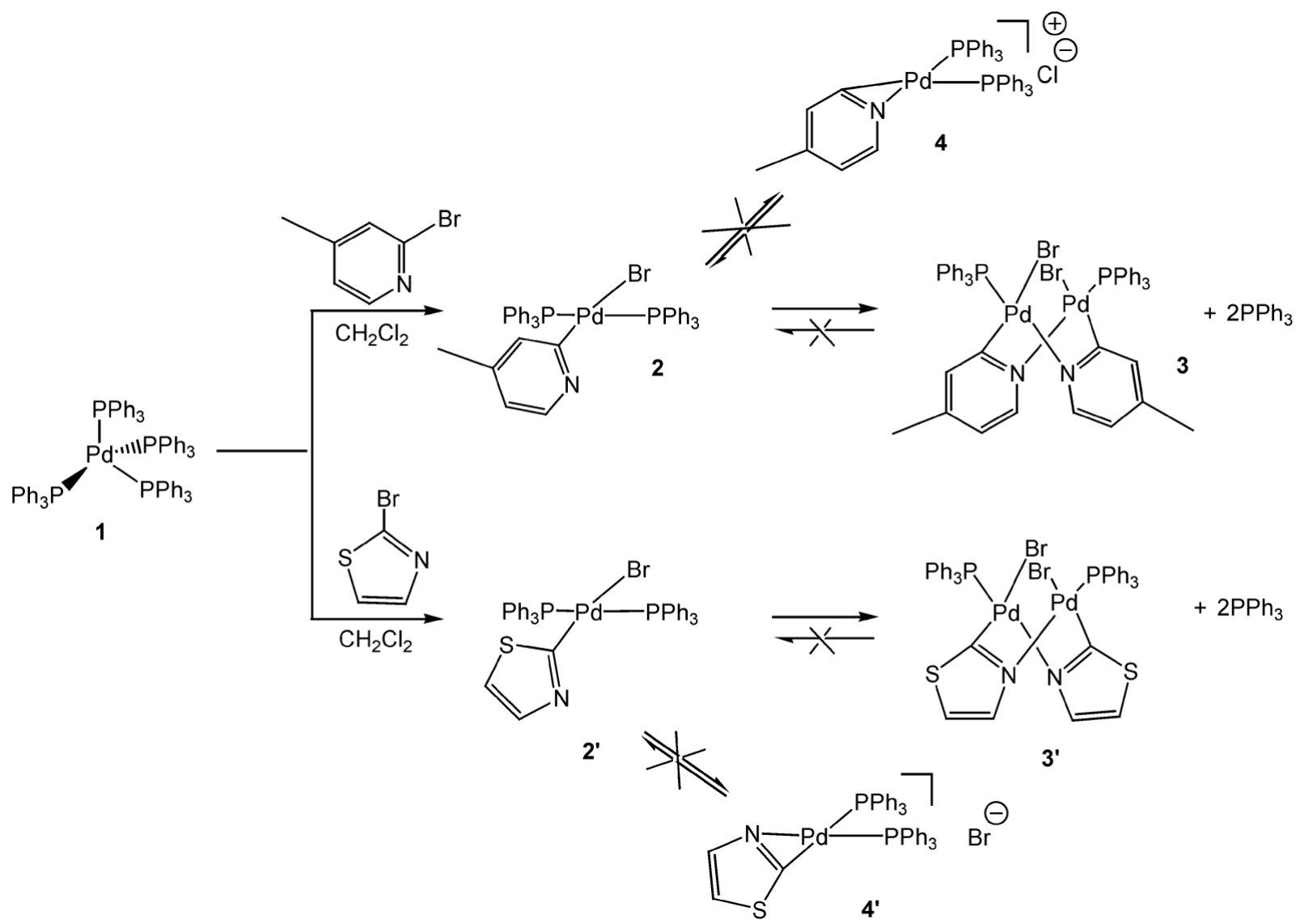

resonance at $\delta 1.60$ for 2 and at $\delta 1.46$ for 3. The ${ }^{13} \mathrm{C}\left\{{ }^{1} \mathrm{H}\right\}$ NMR spectra of $\mathbf{2}$ and $\mathbf{3}$ reveal one singlet at up field, which is assigned to the carbon atom of the methyl group $(\delta 20.6$ and $\delta 20.5)$. It is clear that oxidative addition of 2-bromo4-methylpyridine to the starting complex 1 with releasing two $\mathrm{PPh}_{3}$ molecules was observed. In complex 2, two $\mathrm{PPh}_{3}$ molecules and the 4-methylpyridine and bromide are in the trans position, respectively, and the 4-methylpyridine ligand coordinated to the palladium metal through the carbon atom. In complex $\mathbf{3}$, the NMR data suggest that palladation occurs at the 4-methylpyridine ring and EA suggests that complex 3 contains only one phosphine ligand per metal atom.

The variable low-temperature ${ }^{1} \mathrm{H}$ or ${ }^{31} \mathrm{P}\left\{{ }^{1} \mathrm{H}\right\}$ NMR spectra of $\mathbf{2}$ do not show another sets of proton resonances of methylpyridine or triphenylphosphine resonances from 298 to $223 \mathrm{~K}$ in $\mathrm{CDCl}_{3}$. Within the temperature range, no doublet resonances were observed in the ${ }^{31} \mathrm{P}\left\{{ }^{1} \mathrm{H}\right\} \mathrm{NMR}$ spectra. One can conclude that no intramolecular bromide displacement product $\left[\mathrm{Pd}\left(\mathrm{PPh}_{3}\right)_{2}\left\{\eta^{2}-\mathrm{C}_{5} \mathrm{H}_{3} \mathrm{~N}\left(\mathrm{CH}_{3}\right)\right\}\right][\mathrm{Br}]$,
4, was found. The phenomenon is similar to that of thiazoline Pd complex $\left[\mathrm{Pd}\left(\mathrm{PPh}_{3}\right)_{2}\left(\eta^{1}-\mathrm{CSCHCHN}\right)(\mathrm{Br})\right] .{ }^{10} \mathrm{In}$ the thiocarbamoyl Pd example, complex $\left[\mathrm{Pd}\left(\mathrm{PPh}_{3}\right)_{2}\left(\eta^{1}-\right.\right.$ $\left.\mathrm{SCNMe}_{2}\right)(\mathrm{Cl})$ ], showing the inter- and intramolecular dissociation behavior, was shown to form complexes [Pd$\left.\left(\mathrm{PPh}_{3}\right) \mathrm{Cl}\right]_{2}\left(\mu, \eta^{2}-\mathrm{SCNMe}_{2}\right)_{2}$ and $\left[\mathrm{Pd}\left(\mathrm{PPh}_{3}\right)_{2}\left(\eta^{2}-\mathrm{SCNMe}_{2}\right)\right]-$ $[\mathrm{Cl}]{ }^{8}$

In order to obtain a definitive assignment, X-ray single-crystals diffraction studies were carried out on complexes $\mathbf{2}$ and $\mathbf{3}$. Single crystals of complexes $\mathbf{2}$ and $\mathbf{3}$ were grown by slow diffusion of $n$-hexane into a dichloromethane solution at $4{ }^{\circ} \mathrm{C}$. ORTEP plots of $\mathbf{2}$ and $\mathbf{3}$ are shown in Figs. 1 and 2. Tables 1 and 2 contain crystal data and refinement details and selected bond distances and angles of $\mathbf{2}$ and $\mathbf{3}$. Atomic coordinates and equivalent isotropic displacement coefficients for important atoms of $\mathbf{2}$ and 3 are listed in Table 3. Selected bond distances $(\AA)$ and angles (deg) of $\mathrm{Pd}$ (II) complexes with nitrogen containing ligands are shown in Table 4. In complex 2, the 4-methylpyridine ligand is $\sigma$-bonded to the $\mathrm{Pd}$ atom through the car- 
bon atom. Complex 3 is a dimer with each 4-methylpyridine unit bridging through the carbon atom of the 4-methylpyridine group to one metal center and nitrogen atom to the other metal forming a six-membered ring with boatform geometry. The Pd-Pd bond distance of 3.2254(6) $\AA$ in 3 indicates no bonding interaction between the two metal atoms. It is clear that the 4-methylpyridine nitrogen atom is preferentially bonded and that the triphenylphosphine ligand favors the trans site to the nitrogen donor, which has

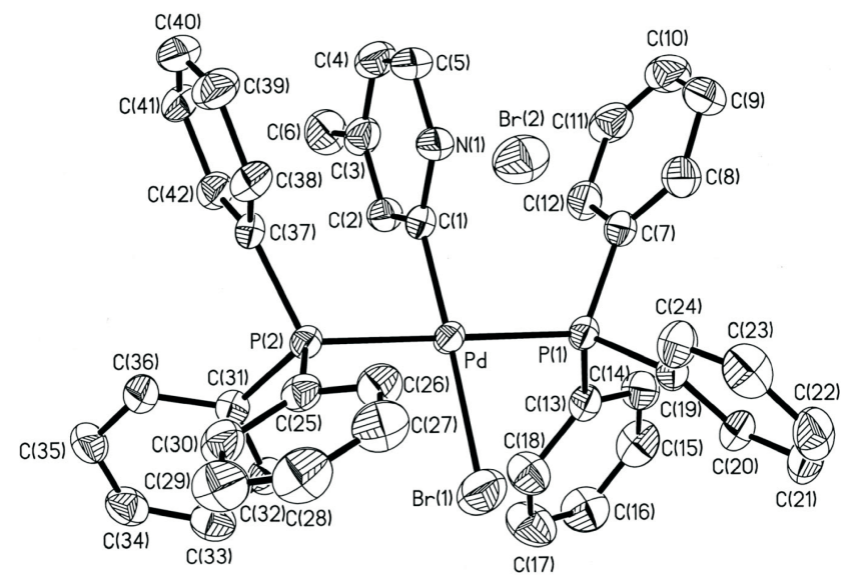

Fig. 1. An ORTEP drawing with $30 \%$ thermal ellipsoids and atom-numbering scheme for the complex $\left[\mathrm{Pd}\left(\mathrm{PPh}_{3}\right)_{2}\left\{\eta^{1}-\mathrm{C}_{5} \mathrm{H}_{3} \mathrm{~N}\left(\mathrm{CH}_{3}\right)\right\}(\mathrm{Br})\right], 2$. a lower trans influence.

In complex 2, the $\mathrm{Pd}$ atom and its neighboring atoms, $\mathrm{P}(1), \mathrm{P}(2), \mathrm{Br}$ and $\mathrm{C}(1)$ lie in a distorted squared plane. A least-squares plane calculation reveals the planarity of the $\mathrm{P}(2) \mathrm{P}(1) \mathrm{C}(1) \mathrm{Br}$ core (largest deviation $0.02 \AA$ ). The $\mathrm{Pd}-\mathrm{N}$ bond distances of 2.896(6) $\AA$ in 2 indicate no bonding interaction between the nitrogen atom and the palladium metal atom. Within the 4-methylpyridine ligands themselves, the geometries are consistent with significant partial double bond character in the $\mathrm{C}(1)-\mathrm{C}(2)$ and $\mathrm{C}(1)-\mathrm{N}(1)$ bonds. Thus, the $\mathrm{C}(1)-\mathrm{C}(2)$ bond distances (1.387(11) $\AA$ of 2 and 1.392(9) $\AA$ (av) of $\mathbf{3}$, ) are comparable to the C-C double bond (1.34 $\AA$ ). The PdC-N bond distances (1.350(9) $\AA$ of 2 and 1.346(8) $\AA$ (av) of 3) are typical for a C-N bond having partial double bond character and are certainly much shorter than the normal C-N (1.47 $\AA$ ) single bond. The Pd-C (1.977 $\AA$ ) and $\mathrm{Pd}-\mathrm{Br}(2.452 \AA)$ lengths for 2 and average Pd-C (1.992 $\AA$ ), Pd-N (2.088 $\AA$ ) and Pd-Br (2.463 $\AA)$ lengths for 3 are in agreement with reported values. ${ }^{11}$ In complex 3, each palladium atom exhibits a square-planar geometry with the bromide and carbon bonds in a trans configuration. The Pd-Pd interatomic distance is 3.2254(6) $\AA$ and is consistent with the structure reported ${ }^{12}$ (3.194(2) $\AA)$ and the chlorine analogue ${ }^{13}(3.165(3) \AA)$, previously published. Reactions of 2 with nucleophiles and finding

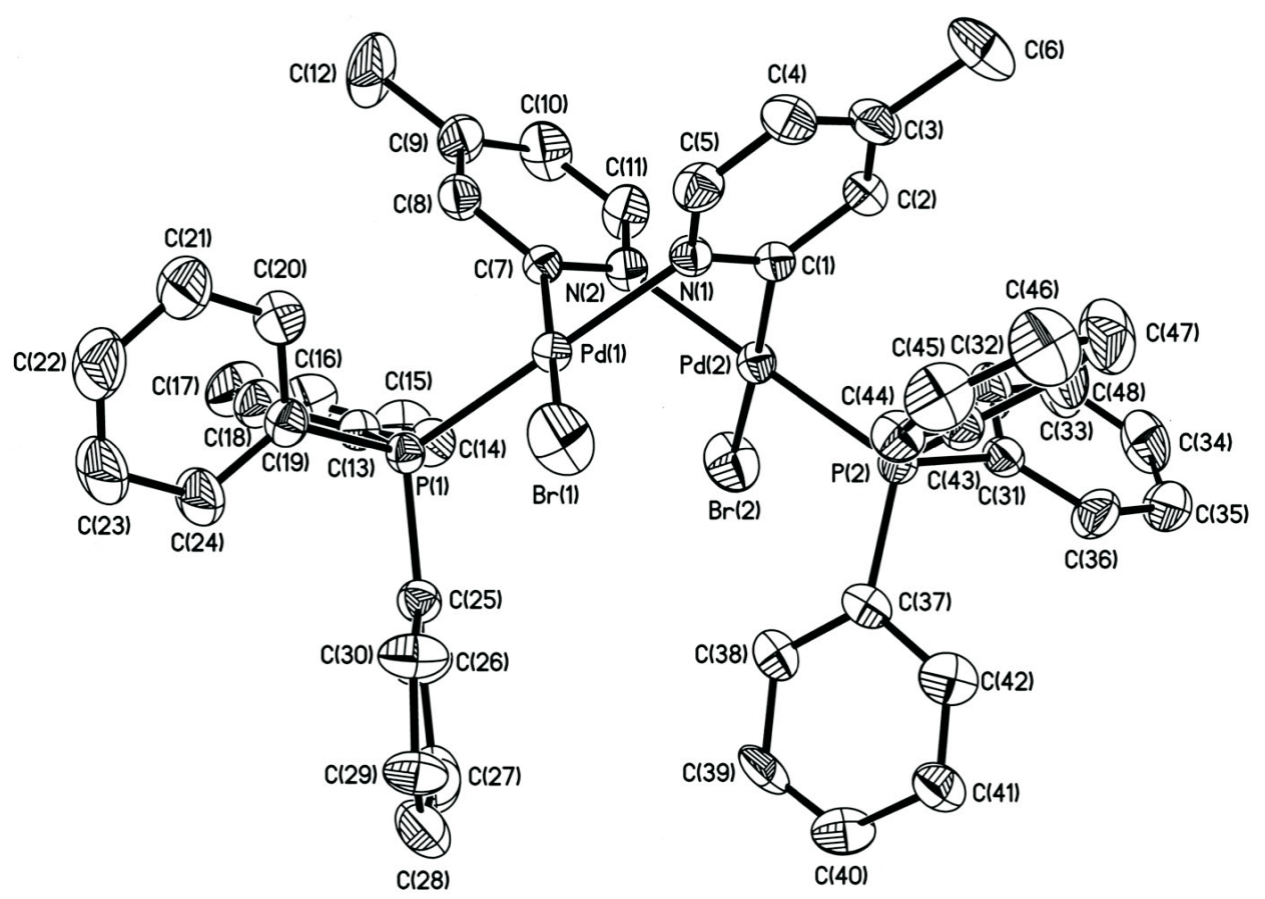

Fig. 2. An ORTEP drawing with $30 \%$ thermal ellipsoids and atom-numbering scheme for the cationic complex $\left[\mathrm{Pd}\left(\mathrm{PPh}_{3}\right) \mathrm{Br}\right]_{2}\left\{\mu, \eta^{2}-\mathrm{C}_{5} \mathrm{H}_{3} \mathrm{~N}\left(\mathrm{CH}_{3}\right)\right\}_{2}, \mathbf{3}$. 
Table 1. Crystal data and refinement details for complexes $2 \cdot 1 / 2 \mathrm{CH}_{2} \mathrm{Cl}_{2}$ and 3

\begin{tabular}{|c|c|c|}
\hline & $2 \cdot 1 / 2 \mathrm{CH}_{2} \mathrm{Cl}_{2}$ & 3 \\
\hline chemical formula & $\mathrm{C}_{42.5} \mathrm{H}_{37} \mathrm{BrClNP}{ }_{2} \mathrm{Pd}$ & $\mathrm{C}_{48} \mathrm{H}_{42} \mathrm{Br}_{2} \mathrm{~N}_{2} \mathrm{P}_{2} \mathrm{Pd}_{2}$ \\
\hline formula weight & 925.34 & 1152.3 \\
\hline crystal system & Monoclinic & triclinic \\
\hline space group & $\mathrm{P} 2(1) / \mathrm{n}$ & $\mathrm{P} \overline{1}$ \\
\hline$a, \AA$ & $20.7030(4)$ & $11.1240(1)$ \\
\hline$b, \AA$ & $9.9002(2)$ & $12.9157(1)$ \\
\hline$c, \AA$ & $21.6198(4)$ & $18.4034(2)$ \\
\hline$\alpha, \operatorname{deg}$ & 90 & $107.1754(6)$ \\
\hline$\beta, \operatorname{deg}$ & $116.9984(9)$ & $91.3173(6)$ \\
\hline$\gamma, \operatorname{deg}$ & 90 & $105.9819(6)$ \\
\hline $\mathrm{V}, \AA^{3}$ & $3948.35(13)$ & $2412.83(4)$ \\
\hline Z & 4 & 2 \\
\hline$\rho_{\text {calcd }}, \mathrm{g} \mathrm{cm}^{-3}$ & 1.557 & 1.586 \\
\hline$\mu,(\mathrm{Mo} \mathrm{K} \alpha), \mathrm{mm}^{-1}$ & 2.673 & 2.612 \\
\hline$\lambda, \AA$ & 0.71073 & 0.71073 \\
\hline$T, \mathrm{~K}$ & $295(2)$ & $295(2)$ \\
\hline$\theta$ range, deg & $1.84-27.50$ & $1.17-27.50$ \\
\hline Independent rflns & 8982 & 11050 \\
\hline no. of variables & 462 & 623 \\
\hline $\mathrm{R}^{\mathrm{a}}$ & 0.085 & 0.070 \\
\hline $\mathrm{R}_{w}{ }^{\mathrm{b}}$ & 0.254 & 0.208 \\
\hline $\mathrm{S}^{\mathrm{c}}$ & 1.019 & 1.029 \\
\hline
\end{tabular}

Table 2. Selected interatomic distances ( $\AA$ ) and angles (deg) for complexes $\mathbf{2}$ and $\mathbf{3}$

\begin{tabular}{|c|c|c|c|}
\hline \multicolumn{2}{|c|}{ Bond lengths } & \multicolumn{2}{|c|}{ Bond angles } \\
\hline \multicolumn{4}{|c|}{ Complex 2} \\
\hline Pd-P(1) & $2.3278(18)$ & $\mathrm{C}(1)-\mathrm{Pd}-\mathrm{Br}(1)$ & $1.762(2)$ \\
\hline $\mathrm{Pd}-\mathrm{P}(2)$ & $2.3332(18)$ & $\mathrm{N}(1)-\mathrm{C}(1)-\mathrm{Pd}$ & $119.8(6)$ \\
\hline Pd-Br(1) & $2.4516(12)$ & P(1)-Pd-P(2) & $177.95(7)$ \\
\hline $\mathrm{Pd}-\mathrm{C}(1)$ & $1.977(7)$ & $\operatorname{Br}(1)-\mathrm{Pd}-\mathrm{P}(1)$ & $90.36(6)$ \\
\hline $\mathrm{C}(1)-\mathrm{C}(2)$ & $1.387(11)$ & $\operatorname{Br}(1)-\mathrm{Pd}-\mathrm{P}(2)$ & $90.60(5)$ \\
\hline $\mathrm{C}(1)-\mathrm{N}(1)$ & $1.350(9)$ & C(1)-Pd-P(2) & $89.5(2)$ \\
\hline $\mathrm{C}(5)-\mathrm{N}(1)$ & $1.362(11)$ & $\mathrm{C}(1)-\mathrm{Pd}-\mathrm{P}(1)$ & $89.5(2)$ \\
\hline$C(3)-C(6)$ & $1.470(14)$ & $C(2)-C(1)-P d$ & $123.8(6)$ \\
\hline \multicolumn{4}{|c|}{ Complex 3} \\
\hline $\mathrm{Pd}(1)-\mathrm{P}(1)$ & $2.2695(16)$ & $C(1)-\operatorname{Pd}(2)-\operatorname{Br}(2)$ & $173.07(18)$ \\
\hline $\mathrm{Pd}(2)-\mathrm{P}(2)$ & $2.2687(17)$ & $C(7)-\operatorname{Pd}(1)-\operatorname{Br}(1)$ & $171.24(18)$ \\
\hline $\operatorname{Pd}(1)-\operatorname{Br}(1)$ & $2.4498(10)$ & $\operatorname{Br}(1)-\operatorname{Pd}(1)-P(1)$ & $92.59(5)$ \\
\hline $\operatorname{Pd}(2)-\operatorname{Br}(2)$ & $2.4755(10)$ & $\operatorname{Br}(2)-\operatorname{Pd}(2)-P(2)$ & $94.00(5)$ \\
\hline $\mathrm{Pd}(2)-\mathrm{C}(1)$ & $1.991(6)$ & $\mathrm{C}(1)-\mathrm{Pd}(2)-\mathrm{P}(2)$ & $91.11(18)$ \\
\hline $\mathrm{Pd}(1)-\mathrm{C}(7)$ & $1.993(6)$ & $C(7)-P d(1)-P(1)$ & $91.93(17)$ \\
\hline $\mathrm{C}(1)-\mathrm{N}(1)$ & $1.345(8)$ & $\mathrm{N}(1)-\mathrm{Pd}(1)-\mathrm{P}(1)$ & $177.44(15)$ \\
\hline $\mathrm{C}(7)-\mathrm{N}(2)$ & $1.347(8)$ & $N(2)-P d(2)-P(2)$ & $176.07(15)$ \\
\hline $\mathrm{Pd}(1)-\mathrm{N}(1)$ & $2.089(5)$ & $\mathrm{N}(1)-\mathrm{C}(1)-\mathrm{Pd}(2)$ & $116.5(4)$ \\
\hline $\mathrm{Pd}(2)-\mathrm{N}(2)$ & $2.088(5)$ & $\mathrm{N}(2)-\mathrm{C}(7)-\mathrm{Pd}(1)$ & $116.8(4)$ \\
\hline $\operatorname{Pd}(1)-\operatorname{Pd}(2)$ & $3.2254(6)$ & & \\
\hline
\end{tabular}

Table 3. Atomic coordinates and equivalent isotropic displacement coefficients for important atoms of $\mathbf{2}$ and $\mathbf{3}$

\begin{tabular}{|c|c|c|c|c|}
\hline Atom & $\mathrm{x}$ & $\mathrm{y}$ & $\mathrm{z}$ & $\mathrm{B}_{\mathrm{eq}}$ \\
\hline \multicolumn{5}{|c|}{ Complex 2} \\
\hline $\mathrm{Pd}$ & $554(1)$ & $-1096(1)$ & $2948(1)$ & $44(1)$ \\
\hline $\operatorname{Br}(1)$ & $678(1)$ & $-44(2)$ & 1981(1) & $97(1)$ \\
\hline $\operatorname{Br}(2)$ & $-404(1)$ & $1586(1)$ & $3593(1)$ & $96(1)$ \\
\hline $\mathrm{P}(1)$ & $-523(1)$ & $-2119(2)$ & 2171(1) & $46(1)$ \\
\hline $\mathrm{P}(2)$ & 1651(1) & $-146(2)$ & $3740(1)$ & $44(1)$ \\
\hline $\mathrm{N}(1)$ & $180(4)$ & $-1430(7)$ & $4078(3)$ & $54(2)$ \\
\hline$C(1)$ & $488(4)$ & $-2049(8)$ & $3721(3)$ & $45(2)$ \\
\hline $\mathrm{C}(2)$ & $760(4)$ & $-3336(8)$ & $3942(4)$ & $53(2)$ \\
\hline$C(3)$ & $742(5)$ & $-3954(9)$ & $4506(4)$ & $62(2)$ \\
\hline \multicolumn{5}{|c|}{ Complex 3} \\
\hline $\operatorname{Pd}(1)$ & $7598(1)$ & $-1033(1)$ & $2768(1)$ & $40(1)$ \\
\hline $\operatorname{Pd}(2)$ & $8237(1)$ & 1432(1) & 2534(1) & 43(1) \\
\hline $\operatorname{Br}(1)$ & $9314(1)$ & $-1736(1)$ & $3077(1)$ & 101(1) \\
\hline $\operatorname{Br}(2)$ & $7649(1)$ & $1488(1)$ & $1244(1)$ & $89(1)$ \\
\hline $\mathrm{P}(1)$ & 6803(1) & $-2570(1)$ & $1717(1)$ & $41(1)$ \\
\hline $\mathrm{P}(2)$ & $10306(2)$ & $2328(1)$ & $2550(1)$ & $45(1)$ \\
\hline $\mathrm{N}(1)$ & $8282(5)$ & $420(4)$ & $3717(3)$ & $45(1)$ \\
\hline $\mathrm{N}(2)$ & $6368(5)$ & $564(4)$ & $2577(3)$ & $48(1)$ \\
\hline$C(1)$ & $8522(6)$ & $1439(5)$ & $3608(4)$ & $45(1)$ \\
\hline $\mathrm{C}(2)$ & $8912(7)$ & $2424(6)$ & $4242(4)$ & $57(2)$ \\
\hline$C(3)$ & $9100(8)$ & $2363(7)$ & $4962(4)$ & $68(2)$ \\
\hline C(4) & $8900(8)$ & $1300(7)$ & $5049(4)$ & $69(2)$ \\
\hline$C(5)$ & $8496(7)$ & $369(7)$ & $4427(4)$ & $60(2)$ \\
\hline$C(6)$ & $9612(13)$ & $3450(10)$ & $5658(6)$ & $111(4)$ \\
\hline$C(7)$ & $6127(6)$ & $-464(5)$ & $2675(3)$ & 44(1) \\
\hline $\mathrm{C}(8)$ & $4912(6)$ & $-1018(6)$ & $2763(4)$ & $57(2)$ \\
\hline $\mathrm{C}(9)$ & $3935(7)$ & $-566(7)$ & $2719(6)$ & $76(2)$ \\
\hline
\end{tabular}

E.S.Ds. refer to the last digit printed.

different bonding modes are currently under investigation. We employ oxidative addition reaction of 2-bromo4-methylpyridine to palladium complex to investigate the bonding mode of 4-methylpyridine. Squared planar geometry, trans-position of the two phosphine ligands and the 4-methylpyridine and bromide ligands, and $\eta^{1}$-4-methylpyridine bonding mode are confirmed by the crystal structure of complex 2. In complex $\mathbf{3}$, the two 4-methylpyridine ligands coordinated through carbon to one metal center and bridging the other metal through nitrogen atom. The nitrogen atom of the 4-methylpyridine ligand assists intermolecular triphenylphosphine displacement of $\mathbf{2}$ to form $\mathbf{3}$.

\section{EXPERIMENTAL SECTION}

\section{General Procedures}

All manipulations were performed under nitrogen using vacuum-line and standard Schlenk techniques. NMR 
Table 4. Selected bond distances $(\AA)$ and angles (deg) of Pd(II) complexes with nitrogen containing ligands

\begin{tabular}{|c|c|c|c|c|c|c|}
\hline $\mathrm{Pd}-\mathrm{C}$ & $1.977(7)$ & $1.993(6)$ & $1.988(5)$ & $1.998(5)$ & $1.982(3)$ & $1.979(4)$ \\
\hline Pd-S & & & 3.229 & $3.297(2)(\mathrm{av})$ & 3.033 & $2.365(3)(\mathrm{av})$ \\
\hline Pd-N & $2.896(6)$ & $2.089(5)(\mathrm{av})$ & 3.046 & $2.085(4)$ & & \\
\hline C-S & & & $1.712(4)$ & $1.722(5)(\mathrm{av})$ & $1.679(4)$ & $1.725(4)(\mathrm{av})$ \\
\hline $\mathrm{C}-\mathrm{N}$ & $1.350(9)$ & $1.346(8)(\mathrm{av})$ & $1.388(10)$ & $1.318(6)(\mathrm{av})$ & $1.320(4)$ & $1.317(5)(\mathrm{av})$ \\
\hline ref & this work & this work & Ref 10 & Ref 10 & Ref 8 & $\operatorname{Ref} 8$ \\
\hline
\end{tabular}

spectra were recorded on an AM-500 WB FT-NMR spectrometer and are reported in units of parts per million with residual protons in the solvent as an internal standard $\left(\mathrm{CDCl}_{3}, \delta\right.$ 7.24). ${ }^{31} \mathrm{P}\left\{{ }^{1} \mathrm{H}\right\}$ NMR spectra were referenced to $85 \% \mathrm{H}_{3} \mathrm{PO}_{4}$ external capillary. IR spectra were measured on a Nicolate Avator-320 instrument and referenced to a polystyrene standard, using cells equipped with calcium fluoride windows. MS spectra were recorded on a JEOL SX-102A spectrometer. Solvents were dried and deoxygenated by refluxing over the appropriate reagents before use. $n$-Hexane and diethyl ether were distilled from sodium-benzophenone. Acetonitrile and dichloromethane were distilled from calcium hydride, and methanol was distilled from magnesium. All other solvents and reagents were of reagent grade and used as received. Elemental analyses and X-ray diffraction studies were carried out at the Regional Center of Analytical Instruments located at National Taiwan University. $\mathrm{PdCl}_{2}$ was purchased from Strem Chemical and 2-bromo-4-methylpyridine was purchased from Merck.

\section{Preparation of $\left[\mathrm{Pd}\left(\mathrm{PPh}_{3}\right)_{2}\left\{\eta^{1}-\mathrm{C}_{5} \mathrm{H}_{3} \mathbf{N}\left(\mathrm{CH}_{3}\right)\right\}(\mathrm{Br})\right], 2$}

2-Bromo-4-methylpyridine $(0.15 \mathrm{~mL}, 1.35 \mathrm{mmol})$ was added to a flask $(100 \mathrm{~mL})$ containing $\mathrm{Pd}\left(\mathrm{PPh}_{3}\right)_{4}$ (1.243 g, $1.0 \mathrm{mmol})$ and $\mathrm{CH}_{2} \mathrm{Cl}_{2}(20 \mathrm{~mL})$ at $-20{ }^{\circ} \mathrm{C}$. The stirred mixture was allowed to warm to room temperature for about $30 \mathrm{~min}$. The solvent was concentrated to $10 \mathrm{~mL}$, and $20 \mathrm{~mL}$ of diethyl ether was added to the solution. The colorless solids were formed which were isolated by filtration (G4), washed with $n$-hexane $(2 \times 10 \mathrm{~mL})$ and subsequently dried under vacuum yielding $0.74 \mathrm{~g}(92 \%)$ of $\left[\mathrm{Pd}\left(\mathrm{PPh}_{3}\right)_{2}\left\{\eta^{1}-\mathrm{C}_{5} \mathrm{H}_{3} \mathrm{~N}\left(\mathrm{CH}_{3}\right)\right\}(\mathrm{Br})\right], 2$. Spectroscopic data for 2: ${ }^{31} \mathrm{P}\left\{{ }^{1} \mathrm{H}\right\} \mathrm{NMR}: \delta 26.6\left(\mathrm{~s}, \mathrm{PPh}_{3}\right) .{ }^{1} \mathrm{H}$ NMR: $\delta 1.60(\mathrm{~s}$, 3H), 7.11-7.62 (m, 33H, Ph, pyridine). ${ }^{13} \mathrm{C}\left\{{ }^{1} \mathrm{H}\right\}$ NMR: $\delta$ $20.6\left(\mathrm{~s}, \mathrm{CH}_{3}\right)$. MS (FAB, NBA, m/z): $804\left[\mathrm{M}^{+}\right]$. Anal. Calcd. for $\mathrm{C}_{42} \mathrm{H}_{36} \mathrm{BrNP}_{2} \mathrm{Pd}$ : C, 62.82; H, 4.52; N, 1.75 . Found: C, 62.95; H, 4.61; N, 1.64 .

\section{Preparation of $\left[\mathbf{P d}\left(\mathbf{P P h}_{3}\right) \mathrm{Br}\right]_{2}\left\{\mu, \eta^{2}-\mathrm{C}_{5} \mathrm{H}_{3} \mathbf{N}\left(\mathrm{CH}_{3}\right)\right\}_{2}, 3$}

$\mathrm{CH}_{2} \mathrm{Cl}_{2}(20 \mathrm{~mL})$ was added to a flask $(100 \mathrm{~mL})$ containing $2(0.802 \mathrm{~g}, 1.0 \mathrm{mmol})$. The solution was stirred for 8 $\mathrm{h}$ then diethyl ether $(30 \mathrm{~mL})$ was added to the solution and a colorless precipitate was formed. The precipitate was collected by filtration (G4), washed with $n$-hexane $(2 \times 10$ $\mathrm{mL}$ ) and then dried in vacuo yielding $0.51 \mathrm{~g}(95 \%)$ of 3 . Spectroscopic data for $3:{ }^{31} \mathrm{P}\left\{{ }^{1} \mathrm{H}\right\}$ NMR: $\delta 30.4\left(\mathrm{~s}, \mathrm{PPh}_{3}\right)$. ${ }^{1} \mathrm{H}$ NMR: $\delta 1.46$ (s, 6H), 7.27-7.84 (m, 36H, Ph, pyridine). ${ }^{13} \mathrm{C}\left\{{ }^{1} \mathrm{H}\right\}$ NMR: $20.5\left(\mathrm{~s}, \mathrm{CH}_{3}\right), 128.4-135.8(\mathrm{~m}, \mathrm{C}$ of $\mathrm{Ph})$. MS (FAB, NBA, $m / z)$ : $1082\left[\mathrm{M}^{+}\right]$. Anal. Calcd for $\mathrm{C}_{48} \mathrm{H}_{42} \mathrm{Br}_{2} \mathrm{~N}_{2} \mathrm{P}_{2} \mathrm{Pd}_{2}$ : C, 53.31; H, 3.92; N, 2.59. Found: $\mathrm{C}$, $53.55 ; \mathrm{H}, 4.11 ; \mathrm{N}, 2.40$.

\section{Single-Crystal X-ray Diffraction Analyses of 2 and 3}

Single crystals of $\mathbf{2}$ and $\mathbf{3}$ suitable for X-ray diffraction analyses were grown by recrystallization from 20:1 $n$-hexane $/ \mathrm{CH}_{2} \mathrm{Cl}_{2}$. The diffraction data were collected at room temperature on an Enraf-Nonius CAD4 diffractometer equipped with graphite-monochromated Mo $\mathrm{K} \alpha(\lambda=$ $0.71073 \AA$ ) radiation. The raw intensity data were converted to structure factor amplitudes and their esd's after correction for scan speed, background, Lorentz, and polarization effects. An empirical absorption correction, based on the azimuthal scan data, was applied to the data. Crystallographic computations were carried out on a Microvax III computer using the NRCC-SDP-VAX structure determination package. ${ }^{14}$

A suitable single crystal of $\mathbf{2}$ was mounted on the top of a glass fiber with glue. Initial lattice parameters were de- 
termined from 24 accurately centered reflections with $\theta$ values in the range from 1.84 to $27.50^{\circ}$. Cell constants and other pertinent data were collected and are recorded in Table 1 . Reflection data were collected using the $\theta / 2 \theta$ scan method. Three check reflections were measured every 30 min throughout the data collection and showed no apparent decay. The merging of equivalent and duplicate reflections gave a total of 39004 unique measured data in which 8982 reflections with $\mathrm{I}>2 \sigma(\mathrm{I})$ were considered observed. The structure was first solved by using the heavy-atom method (Patterson synthesis), which revealed the positions of metal atoms. The remaining atoms were found in a series of alternating difference Fourier maps and least-squares refinements. The quantity minimized by the least-squares program was $\omega\left(\left|F_{\mathrm{o}}\right|-\left|\mathrm{F}_{\mathrm{c}}\right|\right)^{2}$, where $\omega$ is the weight of a given operation. The analytical forms of the scattering factor tables for the neutral atoms were used. ${ }^{15}$ The non-hydrogen atoms were refined anisotropically. Hydrogen atoms were included in the structure factor calculations in their expected positions on the basis of idealized bonding geometry but were not refined in least squares. All hydrogens were assigned isotropic thermal parameters 1-2 $\AA^{2}$ larger than the equivalent Biso value of the atom to which they were bonded. The final residuals of this refinement were $\boldsymbol{R}=$ 0.085 and $\boldsymbol{R} \boldsymbol{w}=0.254$.

The procedure for $\mathbf{3}$ was similar to that for 2 . The final residuals of this refinement were $\boldsymbol{R}=0.070$ and $\boldsymbol{R} \mathbf{w}=0.208$ for 3 . Selected bond distances and angles and selected final atomic coordinates are listed in Tables 2 and 3.

\section{ACKNOWLEDGEMENT}

We thank the National Science Council of Taiwan, the Republic of China, (NSC95-2113-214-001) for support.

Received March 20, 2007.

\section{REFERENCES}

1. Dobrzynski, E. D.; Angelici, R. J. Inorg. Chem. 1975, 14, 1513.

2. (a) Gronowitz, S.; Peters, D. Heterocycles 1990, 30, 645. (b) Dondoni, A.; Fogagnolo, M.; Medici, A.; Nagrini, E. Synthesis 1987, 185.

3. (a) Yamashita, M.; Oda, M.; Hayashi, K.; Kawasaki, I.; Ohta, S. Heterocycles 1998, 48, 2543. (b) Aoyagi, Y.; Inoue, A.; Koizumi, I.; Hashimoto, R.; Tokunaga, K.; Gohma, K.; Komatsu, J.; Sekine, K.; Miyafuji, A.; Konoh, J.; Honma, R.; Akita, Y.; Ohta, A. Heterocycles 1992, 33, 257.

4. Aoyagi, Y.; Mizusaki, T.; Ohta, A. Tetrahedron 1996, 37, 9203.

5. (a) Amatore, C.; Carre, E.; Jutand, A.; M'Barki, M. A.; Meyer, G.. Organometallics 1995, 14, 5605. (b) Amatore, C.; Jutand, A.; M'Barki, M. A. Organometallics 1995, 14, 1818.

6. Chin, C. H.; Yeo, S. L.; Loh, Z. H.; Vittal, J. J.; Henderson, W.; Hor, T. S. A. J. Chem. Soc., Dalton Trans. 1988, 3777.

7. Beeby, A.; Bettington, S.; Fairlamb, I. J. S.; Goeta, A. E.; Kapdi, A. R.; Niemela, E. H.; Thompson, A. L. New. J. Chem. 2004, 28, 600.

8. (a) Lin, Y. C.; Yih, K. H.; Lee, G. H.; Huang, S. L.; Wang, Y. J. Chin. Chem. Soc. 2004, 51, 279. (b) Yih, K. H.; Huang, S. L.; Lee, G. H.; Wang, Y. J. Chin. Chem. Soc. 2004, 51, 493. (c) Yih, K. H.; Lee, G. H.; Wang, Y. J. Chin. Chem. Soc. 2004, 51, 31 .

9. Yih, K. H.; Lee, G. H. J. Chin. Chem. Soc. 2004, 51, 265.

10. Yih, K. H.; Wang, H. F.; Lee, G. H. J. Chin. Chem. Soc. 2007, 54, 553-558.

11. Maitlis, P. M. The Organic Chemistry of Palladium; Academic Press: New York, 1971; Vol. I.

12. Nakatsu, K.; Kinoshita, K.; Kanda, H.; Isobe, K.; Nakamura, A.; Kawaguchi, S. Chem. Lett. 1980, 913.

13. Anderson, T. A.; Barton, R. J.; Robertson, B. E. Acta. Crystallogr., Sect. C 1985, C41, 1171.

14. Gabe, E. J.; Lee, F. L.; Lepage, Y. In Crystallographic Computing 3; Sheldrick, G. M.; Kruger, C.; Goddard, R., Ed.; Clarendon Press: Oxford, 1985; p 167.

15. International Tables for X-ray Crystallography; Reidel: Dordrecht, The Netherlands, 1974; Vol. IV. 